\title{
PENGARUH PEMBERIAN SNACK BAR BERBAHAN DASAR KOMBINASI UBI JALAR UNGU DAN KEDELAI (HITAM DAN KUNING) TERHADAP KADAR TRIGLISERIDA PADA WANITA DEWASA HIPERTRIGLISERIDEMIA
}

\author{
Hesti Ardini Rakhmiditya, Apoina Kartini*) \\ Program Studi Ilmu Gizi Fakultas Kedokteran Universitas Diponegoro \\ Jl.Dr.Sutomo No.18, Semarang, Telp (024) 8453708, Email : gizifk@undip.ac.id
}

\begin{abstract}
Background: Hypertriglyceridemia is one of the risk factor to cardiovascular disease. Anthocyanin and isoflavone could lower triglyceride level in hypertriglyceridemic subject. Purple sweet potato dan soy contain anthocyanin, isoflavone, and fiber. This study was conducted to define the effect of purple sweet potato and soybean snack bar on triglyceride level in adult women with hypertriglyceridemia.

Methods: This is a quasi-experimental study with pre-post test control group design. Subjects are adult women with fasting triglyceride level $>100 \mathrm{mg} / \mathrm{dl}$ which is split into 3 groups: control, treatment group 1, and treatment group 2. Control group was not given any treatment snack, treatment group 1 was given purple sweet potato and black soybean snack bar, and treatment group 2 was given purple sweet potato and yellow soybean snack bar. Treatment was given for 4 consecutive weeks with $80 \mathrm{~g}$ snack bar each day. Triglyceride level was checked on the day before treatment started, $15^{\text {th }}$ day, and $29^{\text {th }}$ day of study. Shaphiro-Wilk Test was used for normality test. Paired t test, Wilcoxon, ANOVA, and Kruskall-Wallis Test were used for data analysis.

Results: Fasting triglyceride level in control group was lower in the $15^{\text {th }}$ day $(p=0.055)$ which could be caused by decreasing energy intake $(p<0.05)$. Treatment group 1 and 2 had increasing intake of energy, fat, and fiber $(p>0.05)$ in the first two week food recall analysis. However, treatment group 2 shows significantly lower fasting triglyceride level $(p=0.011)$ than group $1(p=0.251)$. Fasting triglyceride level check-up on the $29^{\text {th }}$ day shows an increasing level of fasting triglyceride in all the group. ANOVA and Kruskall-Wallis tests shows no difference of triglyceride level between control group, treatment group 1, and treatment group $2(p>0.05)$ in both triglyceride check-up on the $15^{\text {th }}$ and $29^{\text {th }}$ day.

Conclussion: Consumption of $80 \mathrm{~g}$ purple sweet potato and yellow soybean snack bar for 2 consecutive weeks could lower triglyceride level $32.89 \%$ in hypertriglyceridemic adult women $(p=0.023)$.

Keywords: soybean consumption; purple sweet potato; snack bar; triglyceride level; hypertriglyceridemia; adult women
\end{abstract}

\begin{abstract}
ABSTRAK
Latar Belakang: Hipertrigliseridemia merupakan salah satu faktor risiko terjadinya penyakit kardiovaskuler. Antosianin dan isoflavon dapat menurunkan kadar trigliserida. Ubi jalar ungu dan kedelai mengandung antosianin, isoflavon, dan serat. Penelitian ini bertujuan untuk mengetahui pengaruh pemberian snack bar dengan bahan dasar kombinasi ubi jalar ungu dan kedelai terhadap kadar trigliserida pada wanita dewasa hipertrigliseridemia.

Metode: Penelitian yang dilakukan merupakan merupakan quasi-experimental dengan pre-post test control group design dengan subyek wanita dewasa yang memiliki kadar trigliserida puasa >100 mg/dl. Subyek dibagi menjadi 3 kelompok: kontrol (tidak diberikan snack bar), perlakuan 1 (diberikan snack bar kombinasi ubi jalar ungu (Ipomea batatas L) dan kedelai hitam), dan perlakuan 2 (diberikan snack bar berbahan dasar kombinasi ubi jalar ungu (Ipomea batatas L) dan kedelai kuning). Intervensi dilakukan selama 4 minggu dengan dosis snack bar $80 \mathrm{~g}$ sehari. Pemeriksaan kadar trigliserida dilakukan sebelum intervensi, hari ke-15, dan hari ke-29 penelitian. Uji normalitas menggunakan Saphiro-Wilk. Analisis statistik menggunakan paired t-test, Wilcoxon, ANOVA, dan Kruskall-Wallis.

Hasil: Terdapat penurunan kadar trigliserida puasa pada kelompok kontrol $(p>0.05)$ pada pemeriksaan hari ke-15 yang disebabkan oleh penurunan asupan energi $(p<0.05)$. Kelompok perlakuan 1 dan 2 menunjukkan peningkatan asupan energi, lemak, dan serat pada dua minggu awal penelitian. Terjadi penurunan kadar trigliserida pada kelompok perlakuan 2 yang signifikan $(p=0.011)$ dibandingkan kelompok perlakuan $1(p=0.251)$ pada pemeriksaan hari ke-15. Pemeriksaan kadar trigliserida pada hari ke-29 menunjukkan peningkatan dibandingkan hari ke-15. Uji Anova dan Kruskall-Wallis menunjukkan bahwa tidak ada perbedaan kadar trigliserida puasa antara kelompok kontrol, perlakuan 1 dan perlakuan 2 ( $p>0.05$ ) baik pada pemeriksaan hari ke-15 maupun 29.
\end{abstract}

Kesimpulan: Pemberian snack bar berbahan dasar kombinasi ubi jalar ungu dan kedelai kuning dengan dosis 80 sehari selama 2 minggu dapat menurunkan 32.89\% kadar trigliserida pada wanita dewasa hipertrigliseridemia.

Kata kunci: Konsumsi kedelai; ubi jalar ungu; snack bar; kadar trigliserida; hipertrigliseridemia; wanita dewasa 


\section{PENDAHULUAN}

Penyakit kardiovaskuler telah lama menjadi perhatian di kalangan praktisi kesehatan. Jumlah kasus penyakit ini telah mengalami peningkatan selama satu dekade terakhir, terutama di negara dengan pendapatan rendah dan menengah (low-and-middle-incomecountry/LMIC), termasuk Indonesia. ${ }^{1,2}$ Prevalensi penyakit kardiovaskuler diperkirakan akan terus meningkat seiring dengan meningkatnya kasus obesitas, sindrom metabolik, dan diabetes melitus tipe 2. ${ }^{3}$ Sensus yang dilakukan oleh NHANES (National Health and Nutrition Examination Survey) di Amerika Serikat selama dua dekade menunjukkan bahwa rerata kadar trigliserida pada pria dan wanita menunjukkan peningkatan sejak tahun 1976 pada kelompok usia produktif dengan rentang usia 20-49 tahun. ${ }^{4}$ Berdasarkan NCEP (National Cholesterol Education Program) Guidelines tahun 2001, seseorang dikatakan memiliki kondisi hipertrigliseridemia apabila memiliki kadar trigliserida $>150 \mathrm{mg} / \mathrm{dl}$. Namun, pada tahun 2011 American Heart Association (AHA) telah menetapkan standar baru terhadap nilai optimal kadar trigliserida menjadi <100 $\mathrm{mg} / \mathrm{dl}{ }^{4}$

Kejadian hipertrigliseridemia erat kaitannya dengan asupan sehari-hari. Usia, jenis kelamin, aktivitas fisik, konsumsi alkohol, obatobatan, dan penyakit penyerta juga memegang peranan penting dalam munculnya kondisi hipertrigliseridemia. ${ }^{4}$ Pada wanita, menopause meningkatkan kemungkinan terjadi hipertrigliseridemia. Hal ini disebabkan karena berkurangnya produksi estrogen yang mengakibatkan peningkatan kadar serum trigliserida dalam darah. ${ }^{5}$ Salah satu terapi yang dianjurkan yaitu modifikasi gaya hidup dengan pengaturan diet dan olahraga. ${ }^{4}$ Selain membatasi asupan lemak jenuh, penderita hipertrigliseridemia dianjurkan untuk mengurangi asupan karbohidrat sederhana seperti fruktosa dan sukrosa serta meningkatkan asupan protein terutama yang berasal dari kedelai. ${ }^{6,7,8}$

Kedelai mengandung komposisi protein dalam jumlah yang lebih tinggi dibanding sumber pangan nabati lain. Dalam kedelai juga terkandung isoflavon yang dapat menurunkan kadar trigliserida dalam darah. ${ }^{6}$ Selain isoflavon, saponin, serat, dan protein pada kedelai juga turut berperan dalam menurunkan kadar trigliserida. Protein $\beta$ conglycinin, saponin, dan serat pada kedelai bekerja menghambat absorbsi asam lemak sehingga mampu meningkatkan ekskresi trigliserida melalui feses. Serat akan mengikat asam lemak, kolesterol, dan asam empedu yang akan mengurangi pembentukan miselle sehingga lemak tersebut keluar bersama serat melalui feses. ${ }^{9}$

Setiap jenis kedelai memiliki efektivitas yang berbeda dalam menurunkan kadar trigliserida. Berdasarkan penelitian Byun yang menggunakan kedelai hitam, kuning, dan sword bean pada tikus hiperkolesterolemia, kadar serum trigliserida paling rendah ditemukan pada tikus yang diberi kedelai hitam. Kedelai hitam memiliki kandungan protein yang lebih tinggi dibanding kedelai kuning dan sword bean. ${ }^{5}$ Selain itu, kedelai hitam juga mengandung antosianin yang dapat meningkatan oksidasi asam lemak dan menurunkan sintesis asam lemak. ${ }^{10}$

Ubi jalar ungu mengandung berbagai macam antioksidan diantaranya antosianin, vitamin C, vitamin E, dan betakaroten. ${ }^{11}$ Kandungan betakaroten dan antosianin ubi jalar ungu lebih tinggi dibandingkan ubi jalar warna lain. Senyawa antosianin yang terdapat pada ubi jalar ungu adalah cyanidin acyl glucoside dan peonidin acyl glucoside. ${ }^{12}$ Kedua senyawa ini bekerja lebih efektif dibandingkan dengan ubi jalar merah yang mengandung senyawa perlargonidin-3-rutinoside5-glukoside. ${ }^{13}$

Penggunaan ubi jalar ungu dan kedelai sebagai produk makanan dapat berfungsi sebagai pangan fungsional yang dapat menurunkan kadar trigliserida karena kandungan zat gizi di dalamnya. Peneliti tertarik untuk meneliti pengaruh ubi jalar ungu dan kedelai apabila dijadikan produk snack bar dan pengaruh jenis kedelai yang berbeda terhadap penurunan kadar trigliserida pada wanita dewasa hipertrigliseridemia.

\section{METODE}

Penelitian dilakukan di Kantor Setda Provinsi Jawa Tengah pada bulan SeptemberOktober 2013. Penelitian ini merupakan quasi eksperimental dengan pre-post test control group design. Populasi penelitian yaitu wanita dengan hipertrigliseridemia yang bekerja di Kantor Setda Provinsi Jawa Tengah dengan kriteria inklusi belum mengalami menopause, kadar serum trigliserida $>100 \mathrm{mg} / \mathrm{dl}$, tidak memiliki gangguan hormon atau riwayat menderita kanker, gangguan hati atau empedu, penyakit jantung, diabetes mellitus, penyakit ginjal, atau penyakit metabolik lain, tidak mengonsumsi obat-obatan yang berpengaruh pada profil lipid selama 3 bulan terakhir, tidak sedang mengalami kehamilan, dan tidak mengonsumsi alkohol. 
Skrining awal dilakukan setelah sosialisasi penelitian dengan mengajukan permohonan kesediaan menjadi calon subyek. Calon subyek dengan riwayat hipertrigliseridemia diwawancara lebih lanjut dan diminta kesediaannya untuk mengikuti pengambilan darah untuk mengetahui kadar trigliserida awal subyek pada saat itu. Calon subyek dengan hasil pemeriksaan kadar trigliserida $>100 \mathrm{mg} / \mathrm{dl}$ diminta kesediaannya menjadi subyek penelitian dan mengisi formulir informed consent.

Data yg dikumpulkan meliputi identitas subyek, data antropometri, kadar serum trigliserida sebelum dan sesudah intervensi, recall asupan makan (protein, lemak, karbohidrat, serat, dan kolesterol) sebelum dan selama intervensi, dan jumlah konsumsi snack bar. Pencatatan asupan makan dilakukan sebelum dan selama intervensi. Pencatatan asupan makan dilakukan secara acak dalam seminggu. Hal ini menjadi keterbatasan penelitian karena pelaksanaan recall kurang menggambarkan kebiasaan makan subyek saat sedang dinas luar yang dilakukan sewaktu-waktu. Asupan makan dan kebiasaan olahraga subyek tidak dikontrol.

Intervensi dilakukan selama 28 hari. Subyek diperoleh dibagi menjadi menjadi tiga kelompok: kelompok kontrol (tidak diberikan snack bar), kelompok perlakuan 1 (diberikan snack bar berbahan dasar kombinasi ubi jalar ungu dan kedelai hitam), dan kelompok perlakuan 2 (diberikan snack bar berbahan dasar kombinasi ubi jalar ungu dan kedelai kuning). Snack bar diberikan sebanyak dua potong sehari dengan berat masing-masing 40 gr. Snack bar yang diberikan dibuat dengan cara pemanggangan dengan perbandingan komposisi ubi jalar dan kedelai 60:40 serta komposisi ubi jalar ungu $80 \%$ merupakan ubi ungu segar yang telah dikukus dan $20 \%$ dalam bentuk tepung.

Pemeriksaan kadar trigliserida dilakukan dua kali yaitu pada hari ke-15 dan hari ke-29 penelitian menggunakan jasa Laboratorium
Permata. Subyek setiap kelompok berjumlah 10 orang. Selama minggu awal penelitian berlangsung, dua orang subyek dari kelompok perlakuan 2 drop out karena merasa tidak cocok dengan snack bar yang diberikan sehingga tersisa 28 orang yang mengikuti pemeriksaan kadar trigliserida hari ke-15. Sebanyak 5 orang subyek merasa keberatan untuk melanjutkan partisipasi sehingga tersisa 23 orang untuk mengikuti pemeriksaan kadar trigliserida akhir pada hari ke29. Pengukuran berat badan dilakukan pada saat pemeriksaan trigliserida awal dan akhir.

Pengambilan darah dilakukan pada pembuluh darah vena subyek oleh petugas laboratorium pada pagi hari setelah subyek berpuasa selama 10 jam. Penilaian asupan energi, protein, lemak, karbohidrat, serat, dan kolesterol dilakukan dengan menghitung menggunakan software Nutrisurvey kemudian dibandingkan dengan kebutuhan individu subyek.

Batas kemaknaan yang digunakan dalam penelitian ini adalah $\mathrm{p}<0.05$. Normalitas data diuji dengan uji Shapiro-Wilk $(\mathrm{n}<50)$. Analisis deskriptif digunakan untuk melihat gambaran karakteristik subyek serta asupan makan dan kebiasaan olahraga subyek selama penelitian. Uji parametrik ANOVA dan Kruskall Wallis digunakan untuk menguji perbedaan asupan dan kadar trigliserida pada tiga kelompok. Uji hipotesis untuk mengetahui perbedaan kadar serum trigliserida sebelum dan sesudah perlakuan pada kelompok kontrol dan perlakuan dilakukan menggunakan uji parametrik paired t-test dan uji statistik non parametrik Wilcoxon.

\section{HASIL PENELITIAN \\ Kandungan Gizi Snack bar}

Berdasarkan uji kandungan gizi di Laboratorium Ilmu Teknologi Pangan Universitas Muhammadiyah Semarang, diketahui kandungan gizi snack bar seperti yang tercantum pada tabel 1 .

Tabel 1. kandungan gizi snack bar (per 40 gram)

\begin{tabular}{lcc}
\hline $\begin{array}{l}\text { Kandungan } \\
\text { gizi }\end{array}$ & $\begin{array}{c}\text { Snack bar kedelai } \\
\text { hitam }\end{array}$ & $\begin{array}{c}\text { Snack bar kedelai } \\
\text { kuning }\end{array}$ \\
\hline air $(\%)$ & 10,03 & 9,88 \\
abu $(\%)$ & 0,88 & 0,98 \\
protein $(\mathrm{g})$ & 6,55 & 5,34 \\
Lemak $(\mathrm{g})$ & 3,65 & 3,00 \\
Karbohidrat & 18,88 & 21,0 \\
(g) & & \\
\hline
\end{tabular}




\begin{tabular}{lcc}
\hline Energi (kkal) & 134,61 & 131,33 \\
Serat $(\mathrm{g})$ & 1,13 & 1,29 \\
Antosianin & 7,73 & 8,01 \\
$(\mathrm{mg})$ & & \\
Isoflavon $(\mathrm{mg})$ & 404,00 & 496,00 \\
\hline
\end{tabular}

Karakteristik Subyek

Karakteristik subyek sebelum intervensi yang digambarkan meliputi umur dan status gizi subyek (tabel 2). Seluruh subyek yang diambil termasuk pada kategori usia produktif berusia di atas 30 tahun dan belum mengalami menopause.

Tabel 2. Karakteristik Subyek Sebelum Intervensi

\begin{tabular}{|c|c|c|c|c|}
\hline Karakteristik Subyek & Kontrol $(n=10)$ & $\begin{array}{c}\text { Perlakuan } 1 \\
(n=10)\end{array}$ & $\begin{array}{c}\text { Perlakuan } 2 \\
(n=10)\end{array}$ & $\mathbf{p}$ \\
\hline Usia (tahun), rerata (SD) & $45.9(6.49)$ & $45.9(6.42)$ & $49.7(5.34)$ & $0.344^{\mathrm{a}}$ \\
\hline \multicolumn{5}{|l|}{ Kategori Usia, n (\%) } \\
\hline 30-39 tahun & $2(20.0)$ & $1(10.0)$ & $1(12.5)$ & \\
\hline 40-49 tahun & $5(50.0)$ & $7(70.0)$ & $2(25.0)$ & \\
\hline 50-59 tahun & $3(30.0)$ & $2(20.0)$ & $5(62.5)$ & \\
\hline IMT $\left(\mathrm{kg} / \mathrm{m}^{2}\right)$, rerata $(\mathrm{SD})$ & $27.1(4.04)$ & $27.3(4.18)$ & $28.1(4.06)$ & $0.858^{\mathrm{a}}$ \\
\hline \multicolumn{5}{|l|}{ Kategori Status Gizi, n (\%) } \\
\hline Normal $\left(18.5-22.9 \mathrm{~kg} / \mathrm{m}^{2}\right)$ & $1(10.0)$ & $1(10.0)$ & - & \\
\hline Overweight (23.0-24.9 & $3(30.0)$ & $2(20.0)$ & $3(37.5)$ & \\
\hline $\left.\mathrm{kg} / \mathrm{m}^{2}\right)$ & $4(40.0)$ & $4(40.0)$ & $3(37.5)$ & \\
\hline $\begin{array}{l}\text { Obesitas I (25.0-29.9 } \\
\left.\mathrm{kg} / \mathrm{m}^{2}\right)\end{array}$ & $2(20.0)$ & $3(30.0)$ & $2(35.0)$ & \\
\hline \multicolumn{5}{|l|}{ Obesitas $2(>30$ kg/m²) } \\
\hline $\begin{array}{l}\text { Kadar Trigliserida, rerata } \\
\text { (SD) }\end{array}$ & $154.0 \pm 34.69$ & $152.4 \pm 32.33$ & $167.5 \pm 41.77$ & $0.640^{\mathrm{a}}$ \\
\hline Asupan Energi (kkal), rerata & $1249.2(295.13)$ & $1574.3(225.92)$ & $1283.2(219.59)$ & $0.045^{\mathrm{a}^{*}}$ \\
\hline \multicolumn{5}{|l|}{ Kecukupan E (\%) } \\
\hline $\begin{array}{l}\text { Asupan Protein (g), rerata } \\
\text { (SD) }\end{array}$ & $\begin{array}{l}42.1(10.03) \\
82.2(18.94)\end{array}$ & $\begin{array}{l}49.4(13.24) \\
91.8(22.28)\end{array}$ & $\begin{array}{l}43.2(13.38) \\
82.3(26.78)\end{array}$ & $\begin{array}{l}0.494^{\mathrm{a}} \\
0.655^{\mathrm{a}}\end{array}$ \\
\hline \multicolumn{5}{|l|}{ Kecukupan Protein (\%) } \\
\hline $\begin{array}{l}\text { Asupan Lemak (g), rerata } \\
\text { (SD) }\end{array}$ & $\begin{array}{l}36.2(11.53) \\
95.2(31.23)\end{array}$ & $\begin{array}{l}41.7(22.97) \\
103.6(52.83)\end{array}$ & $\begin{array}{l}34.7(11.66) \\
89.4(30.59)\end{array}$ & $\begin{array}{l}0.469^{\mathrm{a}} \\
0.870^{\mathrm{b}}\end{array}$ \\
\hline \multicolumn{5}{|l|}{ Kecukupan Lemak (\%) } \\
\hline $\begin{array}{l}\text { Asupan Karbohidrat (g), } \\
\text { rerata (SD) }\end{array}$ & $\begin{array}{l}191.9(54.61) \\
94.3(29.45)\end{array}$ & $\begin{array}{l}255.7(35.94) \\
124.4(22.83)\end{array}$ & $\begin{array}{l}200.8(54.42) \\
95.8(27.06)\end{array}$ & $\begin{array}{l}0.070^{\mathrm{a}} \\
0.168^{\mathrm{a}}\end{array}$ \\
\hline \multicolumn{5}{|l|}{$\begin{array}{l}\text { Kecukupan Karbohidrat } \\
(\%)\end{array}$} \\
\hline Asupan Serat $(\mathrm{g})$, rerata $(\mathrm{SD})$ & $10.5(4.76)$ & $14.6(5.62)$ & $9.5(6.34)$ & $0.029^{b^{*}}$ \\
\hline Kecukupan Serat (\%) & $59.4(25.98)$ & $69.3(30.04)$ & $51.2(26.67)$ & $0.078^{\mathrm{b}}$ \\
\hline $\begin{array}{l}\text { Asupan Kolesterol (mg), } \\
\text { rerata (SD) }\end{array}$ & $53.8(32.27)$ & 150.7 (136.70) & $126.9(91.44)$ & $0.035^{\mathrm{a}^{*}}$ \\
\hline
\end{tabular}

Perbandingan antara asupan dan kebutuhan zat gizi menghasilkan kecukupan asupan. Kecukupan energi diperoleh dari perbandingan asupan energi dan kebutuhan total individu yang diperoleh menggunakan rumus Mifflin yang dikalikan dengan faktor aktivitas ringan.
Kecukupan karbohidrat, protein, lemak, dan serat diperoleh dari perbandingan asupan dan kebutuhan zat gizi. Kebutuhan karbohidrat dihitung sebagai $60 \%$ dari kebutuhan energi total, protein $15 \%$, dan lemak $25 \%$. Kebutuhan asupan serat diperoleh 
berdasarkan standar kebutuhan serat individu sebanyak $14 \mathrm{gr} / 1000$ kkal kebutuhan energi. ${ }^{9}$

Subyek penelitian tidak memiliki kebiasaan olahraga khusus. Berdasarkan wawancara diketahui bahwa seluruh subyek hanya melakukan olahraga berupa senam pagi yang diadakan Kantor Setda Provinsi Jateng pada hari Jumat. Kegiatan senam berlangsung selama \pm 20 menit.

\section{Asupan Makan dan Persen Kecukupan Gizi Subyek Sebelum Intervensi}

Pada tabel 2 dapat dilihat bahwa asupan makan subyek antar kelompok sebelum intervensi menunjukkan perbedaan pada asupan energi, serat, dan kolesterol $(\mathrm{p}<0.05)$. Persen kecukupan energi subyek antar kelompok tidak menunjukkan perbedaan, sedangkan persen kecukupan serat menunjukkan perbedaan $(\mathrm{p}<0.05)$

Pada tabel 3 dapat dilihat bahwa tidak terdapat perubahan berat badan yang signifikan selama masa intervensi pada ketiga kelompok $(\mathrm{p}>0.05)$.

Tabel 3. Perubahan Berat Badan Selama Intervensi

\begin{tabular}{lcccc}
\hline \multicolumn{1}{c}{ Karakteristik Subyek } & $\begin{array}{c}\text { Kontrol } \\
(\mathbf{n = 1 0})\end{array}$ & $\begin{array}{c}\text { Perlakuan 1 } \\
(\mathbf{n = 1 0})\end{array}$ & $\begin{array}{c}\text { Perlakuan 2 } \\
(\mathbf{n = 1 0})\end{array}$ & $\mathbf{p}^{\mathbf{a}}$ \\
\hline $\begin{array}{l}\text { Berat Badan Awal (kg), } \\
\text { rerata (SD) } \\
\text { Berat Badan Akhir (kg), } \\
\text { rerata (SD) }\end{array}$ & $65.7(10.83)$ & $69.5(13.27)$ & $66.2(8.37)$ & 0.695 \\
$\begin{array}{l}\Delta \text { Berat Badan (kg), rerata } \\
(\mathbf{S D})\end{array}$ & $66.0(11.13)$ & $68.9(13.11)$ & $65.3(7.27)$ & 0.794 \\
$\mathbf{p}^{\mathbf{b}}$ & $0.4(1.21)$ & $-0.6(0.97)$ & $-0.9(1.67)$ & 0.465 \\
\hline
\end{tabular}

${ }^{a}$ ANOVA, ${ }^{b}$ Paired $t$ test

Kecukupan Zat Gizi Subyek Selama Intervensi Penilaian asupan makan dilakukan dua kali yaitu asupan dua minggu pertama (sebelum dilakukan pemeriksaan kadar trigliserida di pertengahan masa intervensi) yang ditunjukkan pada tabel 4. Asupan makan subyek selama dua minggu intervensi menunjukkan perbedaan antara ketiga kelompok pada asupan karbohidrat, protein, dan serat, serta persen kecukupan asupan protein dan serat. Asupan total selama empat minggu antara ketiga kelompok tidak menunjukkan perbedaan $(\mathrm{p}>0.05)$.

Perbedaan asupan energi dan karbohidrat yang bermakna antara asupan sebelum penelitian dan selama penelitian berlangsung terjadi pada kelompok kontrol dan perlakuan 1. Asupan kolesterol mengalami peningkatan yang tidak bermakna secara statistik ( $p>0.05$ ) pada kelompok kontrol selama penelitian berlangsung.

Tabel 4. Kecukupan Zat Gizi Subyek Selama Intervensi

\begin{tabular}{|c|c|c|c|c|c|}
\hline $\begin{array}{c}\text { Karakteristik } \\
\text { Asupan pada } \\
\text { Kelompok } \\
\end{array}$ & $\begin{array}{l}\text { Asupan Pre } \\
(\text { rerata } \pm \text { SD) }\end{array}$ & $\begin{array}{c}\text { Asupan 2 } \\
\text { minggu } \\
\text { (rerata } \pm \text { SD) }\end{array}$ & $\begin{array}{c}p \\
\text { (paired } \\
\text { t test) }\end{array}$ & $\begin{array}{c}\text { Asupan } 4 \\
\text { minggu } \\
\text { (rerata } \pm \text { SD) }\end{array}$ & $\begin{array}{c}p \\
\text { (paired } \\
\text { t test) }\end{array}$ \\
\hline \multicolumn{6}{|l|}{$\begin{array}{l}\text { Kecukupan } \\
\text { asupan Energi }\end{array}$} \\
\hline Kontrol & $110.1(13.29)$ & 110.7 (20.34) & $0.653^{\mathrm{a}}$ & $90.6(18.86)$ & $0.032^{\mathrm{a} *}$ \\
\hline Perlakuan 1 & 91.7 (17.48) & $91.7(19.44)$ & $0.713^{\mathrm{a}}$ & 86.3 (18.87) & $0.488^{\mathrm{a}}$ \\
\hline Perlakuan 2 & & $0.083^{\mathrm{d}}$ & & $0.155^{\mathrm{d}}$ & \\
\hline \multicolumn{6}{|l|}{$\begin{array}{l}\text { Kecukupan } \\
\text { asupan Protein }\end{array}$} \\
\hline Kontrol & $91.8(22.28)$ & $116.1(45.49)$ & $0.331^{\mathrm{a}}$ & $92.4(20.58)$ & $0.962^{\mathrm{a}}$ \\
\hline Perlakuan 1 & $82.3(26.78)$ & $87.3(27.24)$ & $0.748^{\mathrm{a}}$ & $81.1(23.31)$ & $0.796^{\mathrm{a}}$ \\
\hline $\begin{array}{l}\text { Perlakuan } 2 \\
\text { p }\end{array}$ & & $0.032^{\mathrm{d} *}$ & & $0.063^{\mathrm{d}}$ & \\
\hline
\end{tabular}




\begin{tabular}{|c|c|c|c|c|c|}
\hline \multicolumn{6}{|l|}{$\begin{array}{l}\text { Kecukupan } \\
\text { asupan Lemak }\end{array}$} \\
\hline Kontrol & $103.6(52.83)$ & $141.5(56.26)$ & $0.333^{\mathrm{b}}$ & $105.0(45.50)$ & $0.779^{b}$ \\
\hline $\begin{array}{l}\text { Perlakuan } 1 \\
\text { Perlakuan } 2\end{array}$ & $89.4(30.59)$ & $\begin{array}{c}103.9(30.16) \\
0.129^{\mathrm{d}}\end{array}$ & $0.620^{\mathrm{a}}$ & $\begin{array}{c}101.5(23.03) \\
0.484^{\mathrm{d}}\end{array}$ & $0.398^{\mathrm{a}}$ \\
\hline \multicolumn{6}{|l|}{$\begin{array}{l}\text { Kecukupan } \\
\text { asupan }\end{array}$} \\
\hline $\begin{array}{l}\text { Karbohidrat } \\
(\%)\end{array}$ & $\begin{array}{c}94.3(29.45) \\
124.4(22.83)\end{array}$ & $\begin{array}{c}77.0(26.52) \\
104.7(23.47)\end{array}$ & $\begin{array}{l}0.003^{\mathrm{a} *} \\
0.094^{\mathrm{a}}\end{array}$ & $\begin{array}{l}76.2(19.74) \\
84.6(22.30)\end{array}$ & $\begin{array}{l}0.020^{\mathrm{a} *} \\
0.010^{\mathrm{a} *}\end{array}$ \\
\hline $\begin{array}{l}\text { Kontrol } \\
\text { Perlakuan } 1 \\
\text { Perlakuan } 2\end{array}$ & $95.8(27.06)$ & $\begin{array}{c}89.3(15.66) \\
0.080^{\mathrm{d}}\end{array}$ & $0.952^{\mathrm{a}}$ & $\begin{array}{c}85.1(13.62) \\
0.596^{\mathrm{d}}\end{array}$ & $0.335^{\mathrm{a}}$ \\
\hline $\begin{array}{l}\stackrel{p}{\text { Kecukupan }} \\
\text { asupan Serat } \\
(\%)\end{array}$ & $69.3(30.04)$ & $49.3(12.96)$ & $0.286^{\mathrm{a}}$ & $52.7(7.74)$ & $0.531^{\mathrm{a}}$ \\
\hline Kontrol & $59.4(25.98)$ & $64.9(20.34)$ & $0.799^{c}$ & $67.0(17.26)$ & $0.674^{\mathrm{c}}$ \\
\hline $\begin{array}{l}\text { Perlakuan } 1 \\
\text { Perlakuan } 2\end{array}$ & $\begin{array}{c}51.2(26.67) \\
0.078^{\mathrm{c}}\end{array}$ & $\begin{array}{c}59.9(24.89) \\
0.182^{\mathrm{d}}\end{array}$ & $0.263^{\mathrm{c}}$ & $\begin{array}{c}64.1(22.15) \\
0.215^{\mathrm{d}}\end{array}$ & $0.176^{\mathrm{c}}$ \\
\hline $\begin{array}{c}\mathbf{p} \\
\text { Asupan }\end{array}$ & & & & & \\
\hline $\begin{array}{l}\text { Kolesterol (mg) } \\
(\%)\end{array}$ & $\begin{array}{c}53.8(32.27) \\
150.7(136.70)\end{array}$ & $\begin{array}{c}94.5(51.12) \\
116.5(41.81)\end{array}$ & $\begin{array}{l}0.108^{\mathrm{a}} \\
0.407^{\mathrm{a}}\end{array}$ & $\begin{array}{c}97.7(50.32) \\
107.6(51.89)\end{array}$ & $\begin{array}{l}0.054^{\mathrm{a}} \\
0.287^{\mathrm{a}}\end{array}$ \\
\hline $\begin{array}{l}\text { Kontrol } \\
\text { Perlakuan 1 } \\
\text { Perlakuan } 2 \\
\text { p }\end{array}$ & $126.9(91.44)$ & $\begin{array}{c}115.9(84.71) \\
0.314^{\mathrm{d}}\end{array}$ & $0.811^{\mathrm{a}}$ & $\begin{array}{c}111.8(59.80) \\
0.811^{\mathrm{d}}\end{array}$ & $0.731^{\mathrm{a}}$ \\
\hline
\end{tabular}

Perubahan Asupan Makan Selama Intervensi

Terjadi penurunan rerata asupan energi serta karbohidrat dan peningkatan rerata asupan kolesterol pada kelompok kontrol (tabel 5). Kedua kelompok perlakuan menunjukkan penurunan asupan kolesterol. Pada evaluasi asupan 4 minggu rerata asupan serat kelompok kontrol dan perlakuan 1 menunjukkan penurunan sementara kelompok perlakuan 2 menunjukkan peningkatan. Secara statistik tidak terdapat perbedaan antara perubahan asupan antar kelompok selama masa intervensi $(\mathrm{p}>0.05)$.

Tabel 5. Perubahan Asupan Makan Subyek Selama Intervensi

\begin{tabular}{|c|c|c|c|c|}
\hline Zat gizi & Kontrol & Perlakuan 1 & Perlakuan 2 & $\mathbf{p}$ \\
\hline \multicolumn{5}{|l|}{2 minggu } \\
\hline $\mathbf{n}$ & 10 & 10 & 8 & \\
\hline$\Delta$ Energi (kkal) & $-116.6(117.64)$ & $21.6(402.23)$ & $1.2(238.30)$ & $0.277^{\mathrm{a}}$ \\
\hline$\Delta$ Protein $(g)$ & $-4.5(9.59)$ & $14.0(32.63)$ & $2.5(8.16)$ & $0.146^{\mathrm{a}}$ \\
\hline$\Delta$ Lemak (g) & $3.1(12.97)$ & $15.7(27.37)$ & $5.8(13.85)$ & $0.717^{\mathrm{b}}$ \\
\hline$\Delta$ Karbohidrat (g) & $-34.5(32.07)$ & $-20.9(46.78)$ & $-13.5(50.98)$ & $0.239^{\mathrm{a}}$ \\
\hline$\Delta$ Serat $(g)$ & $-2.3(4.29)$ & $1.7(10.07)$ & $0.9(5.32)$ & $0.133^{b}$ \\
\hline$\Delta$ Kolesterol (mg) & $40.8(56.12)$ & $-34.2(157.95)$ & $-10.9(110.70)$ & $0.732^{b}$ \\
\hline
\end{tabular}


${ }^{a}$ anova, ${ }^{b}$ kruskall-wallis

\begin{tabular}{|c|c|c|c|c|}
\hline \multicolumn{5}{|l|}{4 minggu } \\
\hline n & 8 & 8 & 6 & \\
\hline$\Delta$ Energi (kkal) & $-134.6(160.21)$ & $-275.8(322.41)$ & $-76.1(269.33)$ & $0.272^{b}$ \\
\hline$\Delta$ Protein $(g)$ & $-5.3(9.86)$ & $0.6(16.02)$ & $-0.8(6.53)$ & $0.725^{b}$ \\
\hline$\Delta$ Lemak (g) & $2.5(13.72)$ & $5.1(19.01)$ & $4.8(13.08)$ & $0.953^{\mathrm{a}}$ \\
\hline$\Delta$ Karbohidrat & $-35.8(32.99)$ & $-73.2(65.13)$ & $-21.9(56.12)$ & $0.091^{\mathrm{a}}$ \\
\hline$\Delta$ Serat $(g)$ & $-2.1(4.57)$ & $-1.6(8.23)$ & $1.2(4.70)$ & $0.415^{\mathrm{a}}$ \\
\hline$\Delta$ Kolesterol (mg) & $43.9(53.86)$ & $-43.1(117.16)$ & $-15.0(110.73)$ & $0.434^{\mathrm{b}}$ \\
\hline
\end{tabular}

\section{Konsumsi Snack bar}

Jumlah snack bar yang dihabiskan oleh subyek dicatat setiap hari dan dihitung rerata

konsumsi snack bar setiap subyek dalam bentuk persen selama masa intervensi.

\begin{tabular}{llll}
\hline & Perlakuan 1 & Perlakuan 2 & $\mathbf{p}^{\mathbf{a}}$ \\
\hline Konsumsi Snack & & & \\
bar, rerata (SD) & & & \\
Minggu 0-2 & $73.0(10.68)$ & $59.4(13.29)$ & 0.292 \\
Minggu 2-4 & $68.0(14.51)$ & $66.3(16.63)$ & 0.422 \\
\hline
\end{tabular}

${ }^{\mathrm{a}}$ Independent $t$ test

\section{Pengaruh Pemberian Snack bar Terhadap \\ Kadar Trigliserida}

Pada tabel 6 dapat dilihat hasil rerata hasil pemeriksaan kadar trigliserida setiap kelompok pada pemeriksaan awal, pemeriksaan di pertengahan intervensi (minggu ke-2), dan pemeriksaan akhir (minggu ke-4). Uji beda rerata berpasangan menunjukkan perbedaan pada kelompok kuning. Uji statistik untuk membandingkan rerata kadar trigliserida awal, minggu ke-2, dan minggu ke-4 tidak menunjukkan adanya perbedaan rerata antar kelompok $(\mathrm{p}>0.05)$.

Uji dua kelompok tidak berpasangan kadar trigliserida dan delta trigliserida antara kelompok kontrol-perlakuan 1, kontrol perlakuan 2, dan perlakuan1-perlakuan 2 menunjukkan perbedaan $(\mathrm{p}<0.05)$ pada kadar trigliserida minggu ke-4 kelompok kontrol-perlakuan 2 dan delta trigliserida 4 minggu kelompok perlakuan 1perlakuan 2 (lampiran).

Tabel 6. Pengaruh Pemberian Snack bar Terhadap Kadar Trigliserida

\begin{tabular}{lcccc}
\hline & Kontrol & Perlakuan 1 & Perlakuan 2 & p \\
\hline $\begin{array}{c}\text { Pre-test } \\
\text { n }\end{array}$ & 10 & & & \\
kadar TG & $154.0(34.69)$ & $152.4(32.33)$ & $167.5(41.77)$ & $0.640^{\mathrm{c}}$ \\
Minggu ke-2 & & & & \\
n & 10 & 10 & 8 & \\
Kadar TG & $122.4(36.23)$ & $140.7(38.90)$ & $111.0(42.65)$ & $0.280^{\mathrm{c}}$ \\
Delta 0-2 & $-31.1(51.00)$ & $-12.5(28.03)$ & $-55.1(43.33)$ & $0.091^{\mathrm{c}}$ \\
p & $0.055^{\mathrm{a}}$ & $0.251^{\mathrm{a}}$ & $0.011^{\mathrm{a}^{*}}$ & \\
Minggu ke-4 & & & & \\
n & 8 & 8 & 7 & \\
Kadar TG & $157.9(58.16)$ & $163.0(51.12)$ & $130.3(33.44)$ & $0.439^{\mathrm{d}}$ \\
Delta 0-4 & $3.4(45.68)$ & $11.5(68.38)$ & $-35.1(30.69)$ & $0.348^{\mathrm{c}}$ \\
$\mathbf{p}$ & $0.840^{\mathrm{a}}$ & $0.917^{\mathrm{b}}$ & $0.023^{\mathrm{a}^{*}}$ & \\
\hline
\end{tabular}

a paired t-test, ${ }^{\mathrm{b}}$ wilcoxon, ${ }^{\mathrm{c}}$ anova, ${ }^{\mathrm{d}}$ kruskall-wallis

*significant 


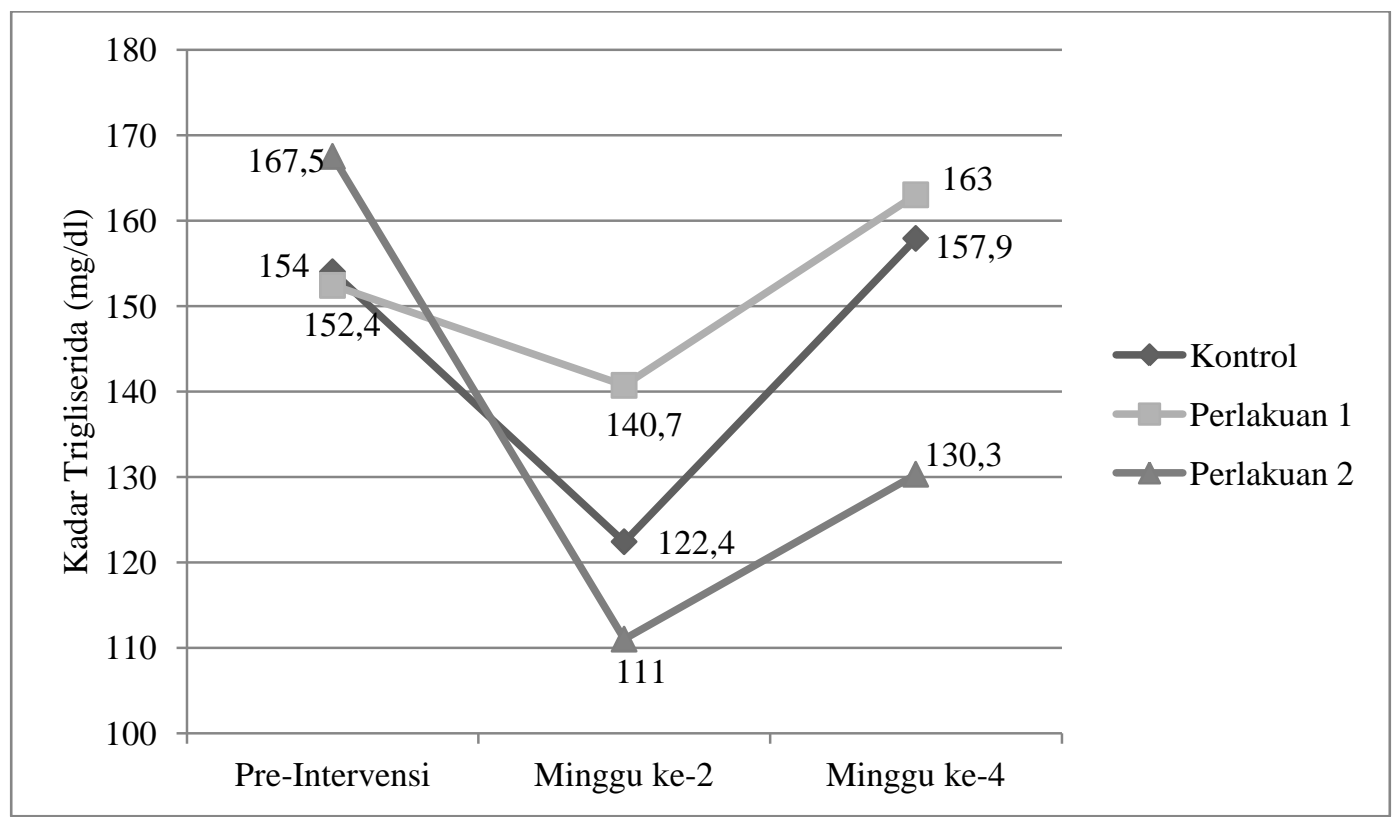

Gambar 1. Perubahan Kadar Trigliserida

\section{PEMBAHASAN}

Uji statistik tidak menunjukkan perbedaan pada kategori usia $(\mathrm{p}=0.344)$ dan indeks massa tubuh $(\mathrm{p}=0.858)$ subyek antar kelompok. Sebanyak 24 subyek $(85.7 \%)$ berusia 40 tahun ke atas dengan rerata ketiga kelompok berkisar antara 45 dan 49 tahun. Sejumlah 26 orang $(92,8 \%)$ subyek berada pada ketegori status gizi overweight atau obesitas dengan rerata indeks massa tubuh (IMT) 27-28 $\mathrm{cm} / \mathrm{kg}^{2}$.

Risiko hipertrigliseridemia pada wanita meningkat seiring dengan pertambahan usia. Wanita dengan usia mendekati menopause cenderung memiliki kadar trigliserida yang lebih tinggi karena produksi hormon estrogen yang semakin berkurang. ${ }^{5}$ Pengaruh estrogen juga dapat dilihat pada penelitian yang menggunakan subyek tikus jantan yang diberi suntikan estradiol. Estradiol meningkatkan ekpresi gen STAT3 sehingga dapat berikatan dengan SREBP-1c promoter dan mencegah transkripsi SREBP-1c. Penurunan transkripsi SREBP-1c akan membatasi aktivitas lipogenik hati. Ekspresi Sterol Regulatory Binding Protein-1c (SREBP-1c) diatur oleh insulin dan berperan mengatur gen yang berfungsi dalam metabolisme glukosa dan asam lemak. SREBP-1c juga berperan dalam biosintesis asam lemak dan kolesterol. ${ }^{14}$

Pemeriksaan kadar trigliserida pada minggu ke-2 menunjukkan penurunan pada ketiga kelompok yang diteliti. Uji statistik paired t test menunjukkan perubahan kadar trigliserida pada kelompok kontrol dan perlakuan 1 merupakan penurunan yang tidak signifikan, sedangkan penurunan pada kelompok perlakuan 2 merupakan penurunan yang signifikan.

Selama dua minggu awal, kelompok kontrol mengalami peningkatan asupan kolesterol $(p>0.05)$ dan penurunan asupan energi $(p<0.05)$ apabila dibandingkan dengan asupan sebelum intervensi. Penurunan asupan energi yang signifikan dapat mempengaruhi penurunan kadar trigliserida kelompok kontrol. Akan tetapi, asupan energi selama 2 minggu awal penelitian masih berada pada kategori cukup ( $>80 \%$ kebutuhan) sehingga tidak menyebabkan penurunan berat badan ( $p>0.05)$. Penelitian menunjukkan bahwa penurunan asupan energi sebesar $300 \mathrm{kkal} / \mathrm{hari}$ dapat menurunkan kadar trigliserida puasa sebanyak 23\%. ${ }^{4} \quad$ Penurunan asupan energi kelompok kontrol pada dua minggu awal penelitian cukup besar (116,6 kkal) dan menunjukkan perbedaan yang bermakna.

Kelompok perlakuan $1 \& 2$ mengalami penurunan kadar trigliserida yang berbeda pada dua minggu awal intervensi. Kedua kelompok mengalami peningkatan asupan energi dan lemak, serta peningkatan asupan serat yang tidak signifikan. Penelitian telah menunjukkan bahwa konsumsi serat dapat menurunkan kadar trigliserida. ${ }^{15}$ Serat dapat berikatan dengan asam lemak, kolesterol, maupun asam empedu dalam 
saluran pencernaan. Pengikatan asam lemak, kolesterol, dan asam empedu oleh serat akan mengurangi pembentukan miselle sehingga lemak tersebut keluar bersama serat melalui feses. ${ }^{9}$

Jenis snack bar yang dikonsumsi memegang peranan penting terhadap penurunan kadar trigliserida kedua kelompok perlakuan pada dua minggu awal penelitian. Hal ini disebabkan adanya perbedaan nilai kandungan nilai gizi pada kedua jenis snack bar sehingga walaupun rerata konsumsi snack bar kelompok perlakuan 1 lebih tinggi daripada kelompok perlakuan 2, penurunan kadar trigliserida yang dialami tidak signifikan apabila dibandingkan dengan kelompok perlakuan 2 .

Snack bar yang diberikan pada kelompok perlakuan 2 (snack bar ubi ungu dan kedelai kuning) mengandung isoflavon dan antosianin yang lebih tinggi dibanding snack bar yang diberikan pada kelompok perlakuan 1 (snack bar ubi ungu dan kedelai kedelai hitam) (Tabel 1). Kedua produk mengalami prosedur yang sama dalam pembuatannya, tetapi antosianin dan isoflavon pada snack bar berbahan dasar ubi jalar ungu dan kedelai hitam menunjukkan kadar yang lebih rendah.

Pembuatan snack bar melalui proses perendaman kedelai, pencucian, pengukusan, dan pemanggangan. Proses tersebut menjadikan isoflavon dan antosianin yang terdapat pada kedelai dan ubi ungu mengalami perubahan nilai gizi. ${ }^{16,17,18}$ Isoflavon kedua jenis kedelai mengalami peningkatan akibat pemanasan karena isoflavon dalam bentuk malonyl glucoside terurai menjadi aglycone dan betaglucoside. ${ }^{19}$ Kadar daidzin, genistin, dan genistein juga menunjukkan peningkatan selama proses perebusan/pengukusan. ${ }^{19}$ Namun, penelitian oleh Xu-Chang menunjukkan bahwa segala bentuk pemanasan dapat mengakibatkan penurunan kadar flavonoid total pada kedelai hitam sehingga kadar isoflavon kedelai hitam lebih rendah daripada kedelai kuning. ${ }^{16}$

Isoflavon bekerja menurunkan trigliserida dengan mengaktifkan faktor transkripsi liganddependent yang disebut dengan Peroxisome Proliferator Activated Receptor (PPAR). PPAR $\alpha$ merupakan salah satu tipe PPAR. Aktivasi PPAR $\alpha$ akan menurunkan kadar trigliserida melalui induksi oleh gen yang bertugas menurunkan ketersediaan trigliserida dalam lipoprotein densitas sangat rendah (VLDL) yang dihasilkan oleh hati dan meningkatkan lipolisis triglyceride-rich plasma lipoprotein seperti kilomikron dan VLDL oleh lipoprotein lipase (LPL). ${ }^{20}$

Proses pemasakan memiliki efek yang berbeda pada antosianin ubi jalar ungu dan kedelai hitam. Segala jenis pemanasan diketahui dapat menurunkan kadar antosianin pada kedelai hitam, sedangkan pemanasan pada ubi jalar ungu dikatahui dapat meningkatkan jumlah antosianin. ${ }^{16,18}$ Selain itu, kedelai hitam juga mengalami perendaman sehingga kadar antosianin menjadi semakin rendah dibandingkan dengan kadar antosianin pada ubi jalar ungu karena terlarut bersama air pada saat perendaman.

Mekanisme yang berkaitan dengan penurunan kadar trigliserida oleh antosianin yaitu antosianin menghambat sintesis kolesterol dengan mengaktifkan adenosine monophosphate-activated protein kinase (AMPK) yang berperan dalam homeostasis energi. AMPK bekerja menghalangi HMG-CoA reduktase yang berperan dalam sintesis kolesterol sehingga pengaktivan AMPK akan menurunkan sintesis kolesterol. AMPK juga menurunkan aktivitas asetil ko-A karboksilase yang akan mengakibatkan peningkatan oksidasi asam lemak dan penurunan sintesis asam lemak sehingga terjadi penurunan konsentrasi kolesterol. $^{10}$

Pemeriksaan kadar trigliserida minggu ke4 menunjukkan peningkatan pada ketiga kelompok apabila dibandingkan dengan kadar trigliserida minggu ke-2. Pada kelompok kontrol, terjadi peningkatan asupan serat serta penurunan asupan energi ( $p>0.05)$ dibandingkan minggu ke-2. Akan tetapi asupan kolesterol selama dua minggu terakhir penelitian menunjukkan peningkatan dibandingkan sebelum intervensi dan dua minggu awal intervensi ( $p>0.05)$.

Kelompok perlakuan 1 menunjukkan kadar trigliserida yang lebih tinggi pada minggu ke-4 dibandingkan kadar trigliserida awal dan minggu ke-2 penelitian. Penurunan asupan energi dan kolesterol yang terjadi $(p>0.05)$ disertai oleh penurunan asupan serat dan konsumsi snack bar yang diberikan $(\mathrm{p}>0.05)$. Penurunan konsumsi snack bar dan kandungan gizi yang lebih rendah pada snack bar kelompok perlakuan 1 mengakibatkan peningkatan kadar trigliserida yang terjadi pada kelompok perlakuan 1 lebih tinggi daripada kelompok perlakuan 2.

Peningkatan kadar trigliserida selama 2 minggu terakhir penelitian pada kelompok perlakuan 2 lebih rendah apabila dibandingkan dengan kelompok perlakuan 1. Namun, kadar trigliserida akhir masih lebih rendah dibandingkan 
dengan kadar trigliserida awal. Tidak terjadi penurunan asupan energi, lemak, dan kolesterol pada kelompok perlakuan 2 selama dua minggu terakhir intervensi. Asupan serat dan konsumsi snack bar menunjukkan peningkatan. Peningkatan kadar trigliserida yang terjadi dapat disebabkan oleh keterbatasan dalam mengumpulkan recall asupan makan subyek selama hari libur atau saat subyek mengadakan dinas luar. Asupan saat dinas luar cenderung meningkat, tetapi subyek kurang dapat mengingat dengan akurat. Hari pengambilan recall juga dapat mempegaruhi reliabilitas data asupan yang diperoleh.

Peningkatan kadar trigliserida juga dapat terjadi karena perubahan aktivitas fisik. Pengaruh aktivitas fisik terhadap kadar trigliserida cenderung berbeda pada setiap individu. Hal ini dipengaruhi oleh kadar trigliserida awal, jumlah kalori yang digunakan, intensitas, dan durasi aktivitas yang dilakukan. ${ }^{4}$ Efek penurunan kadar trigliserida dapat dilihat pada olahraga. Pada olahraga aerobik dengan intensitas rendah $\left(\mathrm{Vo}_{2} \max 25-30 \%\right)$, selama dua jam pertama sumber energi utama yang digunakan berasal dari trigliserida dan asam lemak sehingga mempengaruhi konsentrasi asam lemak pada plasma. Seiring dengan peningkatan level of exercise dan $\mathrm{Vo}_{2}$ max, penggunaan asam lemak bebas menjadi semakin rendah dan sumber energi yang digunakan digantikan oleh glikogen otot. Olahraga dengan intensitas rendah setara dengan berjalan. ${ }^{9}$

Penelitian menunjukkan bahwa mekanisme penurunan kadar trigliserida pada tipe olahraga aerobik dengan intensitas sedang-tinggi disebabkan oleh penurunan sekresi VLDL dan trigliserida hati. Olahraga aerobik dapat menurunkan kadar trigliserida sebanyak $10-20 \%$. Olahraga aerobik intensitas sedang setara dengan berlari 1-3 jam. ${ }^{9}$

\section{SIMPULAN}

Pemberian snack bar berbahan dasar kombinasi ubi jalar ungu dan kedelai kuning dengan dosis $80 \mathrm{~g}$ sehari selama 2 minggu dapat menurunkan rerata kadar trigliserida pada wanita dewasa hipertrigliseridemia. Terjadi penurunan rerata trigliserida yang signifikan $(\mathrm{p}=0.011)$ pada kelompok yang diberi snack bar berbahan dasar kombinasi ubi jalar ungu dan kedelai kuning sebesar $-55.1 \pm 43.33 \mathrm{mg} / \mathrm{dl}$ atau sebesar $32.89 \%$.

\section{SARAN}

Wanita dewasa hiperkolesterolemia dapat mengonsumsi snack bar berbahan dasar ubi jalar ungu dan kedelai kuning untuk menurunkan kadar trigliserida dengan dosis $80 \mathrm{~g}$ sehari sebagai makanan selingan/snack.

\section{DAFTAR PUSTAKA}

1. Mendis S, Puska P, Norrving B, editor. Global Atlas on Cardiovascular Disease Prevention and Control. WHO; 2011. p. 2 - 13. Dapat diakses di: www.who.int

2. The World Bank. Country and Lending Groups. The World Bank; 2013. Dapat diakses di: http://data.worldbank.org/about/countryclassifications/country-and-lending-groups

3. Chapman MJ, Ginsberg HN, Amarenco P, Andreotti F, Boren J, Catapano AL, et al. Triglyceride-rich Lipoprotein and High-Density Lipoprotein Cholesterol in Patients at High Risk of Cardiovascular disease: Evidence and Guidance for Management. European Heart Journal; 2011.

4. Miller M, Stone NJ, Ballantyne C, Bittner V, Criqui MH, Ginsberg HN, et al. Triglycerides and Cardiovascular Disease: A Scientific Statement From the American Heart Assosiation. Circulation; 2011. 123: 2292 - 2333.

5. Byun JS, Han YS, Lee SS. The Effects of Yellow Soybean, Black Soybean, and Sword Bean on Lipid Levels and Oxidative Stress in Ovariectomized Rats. Int. J. Vitam. Nutr. Res., 80 (2); 2010. p. 97 106.

6. Xiao CW. Health Effects of Soy Protein and Isoflavons in Humans. J. Nutr; 2008. 138: 1244S 1249S.

7. Fried SK, Rao SP. Sugars, Hypertriglyceridemia, and Cardiovascular Disease. Am J Clin Nutr; 2003. 78(suppl):873S-80S.

8. Teff KL, Elliot SS, Tschop M, Kiefer T, Rader D, Heiman M, et al. Dietary Fructose Reduces Circulating Insulin and Leptin, Attennuates Postprandial Suppression of Ghrelin and Increases Triglyceride in Women. J Clin Endocrinol Metab; 2004. (89): 2963-2972.

9. Gropper SS, Smith JL, Groff JL. Advanced Nutrition and Human Metabolism. $5^{\text {th }}$ ed. California: Wadsworth; 2009.

10. Graf D, Seifert S, Jaudszus A, Bub A, Watzl B. Anthocyanin-Rich Juice Lower Serum Cholesterol, Leptin, and Resistin and Improves Plasma Fatty Acid Composition in Fischer Rats. PLoS ONE; 2013. 8(6): e66690.

11. Nintami AL, Rustanti N. Kadar Serat, Aktivitas Antioksidan, Amilosa, dan Uji Kesukaan Mi Basah dengan Substitusi Tepung Ubi Jalar Ungu (Ipomoea batatas var Ayamurasaki) bagi Penderita Diabates Melitus Tipe 2. Journal of Nutrition College, Vol 1; 2012. 1: 486 - 504.

12. Yulistiani R, Murtiningsih, Mahmud M. Peran Pektin dan Sukrosa pada Selai Ubi Jalar Ungu. Artikel Penelitian. Jawa Timur: Program Studi Teknologi Pangan FTI UPN. 
13. Hardoko, Hendarto L, Siregar TM. Pemanfaatan Ubi Jalar Ungu (Ipomoea batatas L. Poir) sebagai Pengganti Sebagian Tepung Terigu Sumber Antioksidan pada Roti Tawar. J Teknol dan Industri Pangan, Vol XXI; 2010. 1: 25 - 32.

14. Miller CN, Mary Anne D, Baile CA. The Mediation of Hepatic Lipogenesis Through Estrogens. Journal of Postdoctoral Research; 2013. 1(5): 27-38.

15. Liu S. Intake of Refined Carbohydrates and Whole Grain Foods in Relation to Risk of Type 2 Diabetes Mellitus and Coronary Heart Disease. Journal of the American College of Nutrition Vol. 21; 2002. 4:298 - 306.

16. Xu B, Chang SK. Total phenolics, phenolic acids, isoflavones, and anthocyanins and antioxidant properties of yellow and black soybeans as affected by thermal processing. J Agric Food Chem; 2008. 56(16):7165.

17. Montilla EC, Hillebrand S, Winterhalter P. Anthocyanins in Purple Sweet Potato (Ipomoea batatas L.) Varieties. Fruit, Vegetable and Cereal Science and Biotechnology; 2011. p: 19-24.

18. Lemos MA, Aliyu MM, Kynoch G, Joseph LR, Hungerford G. Effect of Cooking on the Levels of Bioactive Compounds in Purple Majesty Potato. InsideFood Symposium; 2013. Belgium.

19. Araujo MM, Fanaro GB, Haasis Villavicencio ALC. Soybean and Isoflavones-From Farm to Fork. Intech; 2013.

20. Medjakovic S, Mueller M, Jungbauer A. Potential Health-Modulating Effect of Isoflavones and Metabolites via Activation of PPAR and AhR. Nutrients; 2010. 2: 241-279. 